\title{
Initiatief Comprehensive Prostate Cancer Network (CPCN) in Zuidoost Nederland
}

\author{
Jean-Paul A. van Basten ${ }^{1} \cdot$ Rik M. Somford $^{1} \cdot$ Joost de Baaij $^{1} \cdot$ Michiel Sedelaar $^{2} \cdot$ Eric $^{\text {Vrijhof }^{3}}$
}

Published online: 12 September 2017

(c) The Author(s) 2017. This article is an open access publication.

Samenvatting De huidige diagnostiek en behandeling van prostaatkankerzorg is complex. Zeker complexe interventies, zoals robotprostatectomie, vragen om concentratie, teneinde een goed meetbaar optimaal kwaliteitsniveau te kunnen behalen. Volume is noodzakelijk om kortcyclische kwaliteitsverbeteringen te kunnen implementeren en evalueren. Tevens is volume nodig om een doorlopend inzicht te geven aan alle betrokken medische en verpleegkundige zorgprofessionals en om een optimale logistieke en kwaliteitsstructuur te kunnen neerzetten. In regionale Comprehensive Prostate Cancer Networks (CPCNs) is zorg geconcentreerd waar nodig en dichtbij huis indien mogelijk. Daarbij is er een nadrukkelijke rol voor elk ziekenhuislid, in samenwerking met de eerste lijn. Het uitgangspunt van een $\mathrm{CPCN}$ is om op alle locaties binnen dit netwerk hetzelfde niveau van zorg te leveren, middels uniformering van informatie, diagnostiek, zorgpaden, deelname aan kwaliteitsindicatoren, waaronder de Patient Reported Outcome Measures (PROMs), continue monitoring, kwaliteitsverbetering en wetenschap. Samenwerking volgens de zorglijnen biedt niet alleen voordelen voor de patiënt, maar zeker ook voor de participerende instanties. Een dergelijke samenwerking is immers kostenefficiënt en zal overdiagnostiek en -behandeling reduceren. Verbetering van uitkomsten en van processen, én kostenbeheersing, worden gerealiseerd

dr. Jean-Paul A. van Basten

j.v.basten@cwz.nl

1 afdeling Urologie, Canisius-Wilhelmina ziekenhuis Santeon, Nijmegen, Nederland

2 afdeling Urologie, Radboud Universitair Medisch Centrum, Nijmegen, Nederland

3 afdeling Urologie, Catharina ziekenhuis Santeon, Eindhoven, Nederland volgens de value based health care (VBHC) methodiek van Santeon. Dit artikel beschrijft de initiatieven die in onze regio worden ontplooid, die samen een eerste aanzet vormen tot een dergelijke CPCN.

Trefwoorden prostaatkankernetwerk $\cdot$ regionalisatie value based health care

\section{Initiative Comprehensive Prostate Cancer Network in South-East Netherlands}

Abstract The current diagnostics and therapies of prostate cancer is complex. Complex interventions such as robotassisted radical prostatectomies require concentration in order to achieve a measurable optimal quality level. Volume is necessary to implement and evaluate short-cyclical quality improvements. In addition, volume is needed to provide continuous insight to all involved medical and nursing care professionals and to create an optimal logistic and quality structure. In regional Comprehensive Prostate Cancer Networks (CPCNs) care is concentrated where necessary and close to home if possible. In addition, there is an emphatic role for each hospital member, in collaboration with the first line. The starting point of a CPCN is to provide the same level of care at all locations within this network, through information uniformity, diagnostics, care paths, participation in quality indicators, including Patient Reported Outcome Measures (PROMs), continuous monitoring, quality improvement and science. Collaboration on the medical care lines offers not only benefits for the patient, but also for the participating agencies. Such cooperation is cost-effective and will reduce overdiagnostics and unnecessary treatment. Improvement of outcomes and processes, and cost control, are realized according to Santeon's value 
based health care methodology. This article describes the initiatives in our region, which together form a first step towards such a CPCN.

Keywords prostate cancer network - regionalization . value based health care

\section{Introductie}

"Bijwerkingen van de operatieve behandeling van prostaatkanker kunnen aanzienlijk beperkt worden wanneer de behandeling wordt geconcentreerd in een beperkt aantal centra. In de Martini-Klinik in Hamburg is daarvan al een best practice beschikbaar. Jaarlijks komen daar 2200 gevallen binnen", meldde CZ-bestuursvoorzitter Wim van der Meeren vorig jaar [1]. Aansluitend volgde op 14 juli een persbericht van Santeon, met de mededeling dat deze ziekenhuisketen in samenwerking met het ErasmusMC en Radboudumc zal starten met het concentreren van de radicale prostatectomieën op een beperkt aantal locaties binnen haar netwerk [2].

In heel Nederland werden in 2016 rond de 2100 radicale prostatectomieën uitgevoerd. Minder dus dan in de Martini-Klinik in Hamburg. Slechts zeven Nederlandse ziekenhuizen voerden vorig jaar meer dan 100 van dergelijke operaties uit [3]. De Nederlandse Vereniging voor Urologie (NVU) hanteert als minimum volumenorm 20 radicale prostatectomieën per ziekenhuis. Dat aantal is te laag om betrouwbaar de uitkomsten te kunnen meten en vergelijken, laat staan kortcyclisch te evalueren en te verbeteren. De NVU heeft derhalve, op instigatie van de Werkgroep Oncologische Urologie (WOU), alsmede op aandringen van Zorgverzekeraars Nederland (ZN) en de Prostaat Kanker Stichting (PKS), de volumenorm met ingang van 1 januari 2018 op minimaal 50 ingrepen per ziekenhuis gesteld.

Dat bij het vaker uitvoeren van complexe behandelingen, zoals een robotgeassisteerde radicale prostatectomie (RARP), de ervaring van het chirurgische team groter wordt en daardoor de operatie-uitkomsten beter zullen zijn, is aannemelijk [4]. De leercurve voor de complexe (robot)operatie is immers lang en dat betekent dat je veel ingrepen moet doen om ten aanzien van uitkomsten een plateaufase te bereiken. Het exacte aantal om de leercurve voor RARP te doorlopen, is onbekend, en waarschijnlijk afhankelijk van training, mate van expositie, intensiteit van de begeleiding en het talent van de operateur. Een recente analyse van 140.671 patiënten die tussen 2009 en 2011 in de Verenigde Staten een RARP ondergingen, liet zien dat een volume van 100 of meer ingrepen per jaar tot betere perioperatieve uitkomsten leidt [5].

Dat volume een belangrijke factor voor uitkomst is, wordt gesteund door de bevindingen vanuit het Santeon- project 'Zorg voor Uitkomst' (ZvU) dat sinds 2013 de uitkomsten voor alle prostaatkankerpatiënten binnen de Santeon-groep monitort. Uit deze analyse bleek dat in de hoogvolume chirurgische centra de uitkomsten beter waren dan in de laagvolumecentra, zowel wat betreft oncologische uitkomsten (snijvlakken en postoperatief onmeetbaar PSA), als het percentage chirurgische complicaties. Deze bevinding heeft er mede toe bijgedragen dat twee relatief dicht bij elkaar gelegen Santeon-partners, Catharina Ziekenhuis Eindhoven (CZE) en Canisius Wilhelmina Ziekenhuis (CWZ) Nijmegen, de handen ineen hebben geslagen en sinds 2013 de radicale prostatectomieën op één locatie uitvoeren. Deze transitie heeft, samen met de uitkomstenfeedback op operateursniveau per kwartaal, het aantal positieve snijvlakken gereduceerd en het complicatiepercentage gehalveerd voor patiënten van beide ziekenhuizen [6].

Reden voor het Radboudumc om vanaf september 2016 ook aan te sluiten bij de CZE-CWZ-alliantie, wat impliceert dat ook het Radboudumc haar RARP'en op locatie CWZ verricht, en deelneemt aan de interne kwaliteitsanalyses, multidisciplinair overleg (MDO), wetenschappelijk onderzoek etc. Dit samenwerkingsverband is voor meerdere jaren juridisch gekaderd.

Binnen Santeon hebben de $\mathrm{ZvU}$-bevindingen geleid tot discussie over verregaande schaalvergroting, aangewakkerd door het maatschappelijke debat over concentratie van complexe oncologische behandelingen (o. a. geïnitieerd vanuit de patiëntenverenigingen en de zorgverzekeraars). In vervolg hierop is op projectbasis bestudeerd of concentratie van prostaatkankerzorg in haar volle breedte op één locatie haalbaar zou zijn, in samenwerking met een academisch ziekenhuis met een wetenschappelijk track record op het domein van prostaatkanker (naar analogie van het samenwerkingsmodel tussen de Martini Kliniek en de Universiteit Eppendorf-Hamburg) [2]. Dit bleek na zorgvuldige analyse onwenselijk, omdat daarmee belangrijke onderdelen van de prostaatkankerketen uit (bepaalde) regio's zou verdwijnen. Binnen Santeon is toen besloten tot een regionale aanpak, waarbij de hoogcomplexe onderdelen van de zorgketen in de regio worden geconcentreerd, maar waarbij de diagnostiek en nazorg in alle ziekenhuizen beschikbaar blijven.

In Nederland zijn er reeds dergelijke CPCN-initiatieven, waarin complexe onderdelen van het zorgtraject geconcentreerd zijn omwille van maximale expertise en optimale uitkomst, zoals het samenwerkingsverband Anser-kliniek, EmBraZe, ONCO-ZON, Prostaat Centrum Noord-Nederland (UMCG/Treant Zorggroep en de Ommelander Zorggroep), Alliantie Regionale Topzorg (Rijnstate-Gelderse Vallei-Slingeland), en het samenwerkingsverband CZE, CWZ en Radboudumc.

Deze initiatieven maken duidelijk dat complexe interventies vragen om concentratie, teneinde een goed meetbaar 
en optimaal kwaliteitsniveau te kunnen behalen. Een zeker volume is immers noodzakelijk om kort-cyclische kwaliteitsverbeteringen te kunnen implementeren en evalueren. Tevens is volume nodig om een doorlopend inzicht te geven aan alle betrokken medische en verpleegkundige zorgprofessionals, waaronder ook operatieassistenten en afdelingsverpleegkundigen, en om een optimale logistieke en kwaliteitsstructuur te kunnen neerzetten.

Toch is niet iedereen enthousiast. De landelijke ontwikkeling van concentratie van complexe zorg in zogeheten expertisecentra wordt ook als bedreigend ervaren, en de berichtgevingen hieromtrent hebben vorig jaar tot veel commotie geleid. Concentratie zou leiden tot echelonvorming van de ziekenhuizen, een kwalificatierangorde impliceren en een kaalslag in de periferie geven, zo is de gedachte. Dat is natuurlijk niet de bedoeling. Doelen zijn immers de concentratie van kennis en kunde, de minimalisering van praktijkvariatie ten aanzien van informatie en uitkomsten, en het met elkaar creëren van een platform voor wetenschap, onderwijs en innovatie. Het is glashelder dat zorg dichtbij huis enorme voordelen biedt voor patiënt en naasten, zeker in latere stadia van een ziekteproces.

Omdat prostaatkankerzorg zoveel meer omvat dan radicale prostatectomie, pleiten wij voor regionale Comprehensive Prostate Cancer Networks (CPCNs), waarin nadrukkelijk een rol is weggelegd voor elk participerend ziekenhuis, zowel in het netwerk, als bij de samenwerking met de eerste lijn. Daarbij is een regiefunctie weggelegd voor het regionale ziekenhuis, met een sterk profiel op het gebied van prostaatkanker. Uitgangspunt is dat op alle locaties binnen dit netwerk hetzelfde niveau van zorg wordt geleverd middels uniformering van informatie, diagnostiek, zorgpaden en deelname aan kwaliteitsindicatoren, waaronder de $\mathrm{Pa}$ tient Reported Outcome Measures (PROMs), continue monitoring, kwaliteitsverbetering en wetenschap. Samenwerking biedt niet alleen voordelen voor de patiënt, maar zeker ook voor de participerende instanties. Samenwerking is tevens kostenefficiënt en zal overdiagnostiek en -behandeling reduceren.

Graag informeren wij u over de in onze regio ontplooide initiatieven, die samen een eerste aanzet vormen tot een dergelijke CPCN.

\section{Value based health care}

Binnen het Santeon-project $\mathrm{ZvU}$ is een beperkte set kwaliteitsindicatoren voor prostaatkanker vastgesteld, in samenwerking met International Consortium of Health Outcome Measurement (ICHOM). Dit maakt dat uitkomsten niet alleen tussen de Santeon-ziekenhuizen onderling vergeleken kunnen worden, maar ook internationaal, bijvoorbeeld met Martini-Hamburg. Retrospectief zijn de gevraagde data vanaf 2008 door werkstudenten verzameld en door datamanagers geanalyseerd en gebenchmarkt. De uitkomsten zijn transparant en gepubliceerd in uitkomstenboeken [7].

Verschillen werden in $\mathrm{ZvU}$ weliswaar bediscussieerd, maar leverden Santeon-breed geen concrete verbeterinitiatieven op, behoudens de Santeon-rekenregel voor curatieve therapie; cijfers wezen uit dat de vijfjaarsoverleving in de gehele groep in opzet curatief behandelde patiënten met $95 \%$ conform de verwachtingen was. Echter, bij een subgroep patiënten met meer comorbiditeit (14\% van de totale populatie), bedroeg de overleving slechts $83 \%$. Op grond van deze getallen kijken we nog kritischer naar de indicatiestelling voor RARP. Daarmee is het niet de bedoeling om patiënten met comorbiditeit per definitie uit te sluiten van chirurgie, maar deze getallen worden zeker meegenomen in het gesprek met de patiënt, met een rekenregel op basis van leeftijd, comorbiditeit (Charlson-score) en tumorgraad (Gleason-score) als hulpmiddel [8].

$\mathrm{ZvU}$ evolueerde tot het value based health care (VBHC) principe, met als uitgangspunt dat diagnostiek en behandeling toegevoegde waarde heeft voor levensverwachting en -kwaliteit. De patiënt moet immers kunnen rekenen op optimale oncologische zorg die is afgestemd op zijn individuele wensen en behoeften. Dat proberen we binnen dit VBHC-careprogramma te realiseren middels twee cycli per jaar, waarbij binnen Santeon gezamenlijk gekeken wordt naar de variatie en vervolgens een concreet verbeterdoel wordt gesteld. Zo is bijvoorbeeld bij de laatste evaluatie opgevallen dat er veel variatie is in radiologisch onderzoek naar (lymfeklier)metastasen dat werd ingezet. De conclusie was dat gestreefd moet worden naar uniforme zinnige diagnostiek en dat derhalve een Santeon-uniform diagnostisch traject wenselijk is. Dit is momenteel in ontwikkeling en binnen onze regio zal verbinding worden gezocht met het reeds bestaande gezamenlijke zorgpad van Radboudumc en het Jeroen Bosch Ziekenhuis (JBZ).

Daarnaast kiest elk Santeon-ziekenhuis zijn eigen verbeterthema. Dit gebeurt met hulp van lokale verbeterteams, die bestaan uit een vertegenwoordiging van de bij prostaatkankerzorg betrokken disciplines, alsmede een ervaringsdeskundige c.q. patiënt.

Duidelijk is dat we van elkaar kunnen leren. Zo bleek uit patiënteninterviews dat er in het CWZ een gemis aan psychoseksuele begeleiding en groepsvoorlichting wordt ervaren. Daarentegen is psychoseksuele begeleiding in Radboudumc goed op orde en dit geldt ook voor de groepsvoorlichting in het CZE. De CWZ-verpleegkundigen hebben zo, binnen het netwerkcontact, een goed voorbeeld voor implementatie, en er vindt kruisbestuiving plaats.

Santeon is twee jaar geleden gestart met verzamelen van PROMs, zoals deze zijn opgesteld door de werkgroep van het International Consortium for Health Outcomes Measurement (ICHOM), waarbij de EQ-5D Algemene ge- 
zondheid en de Expanded Prostate Cancer Index Composite (EPIC-26) worden afgenomen, aangevuld met vragen over seksueel functioneren uit de Utilization of Sexual Medications/Devices en de EORTC QLQ-PR-25 (voor evaluatie van de kwaliteit van leven bij prostaatkanker) [9]. Sinds kort worden deze vragen aan alle prostaatkankerpatiënten verstuurd en worden de samengevoegde set antwoorden rechtstreeks teruggekoppeld aan de zorgprofessionals, middels het digitale systeem Questmanager van Vital Health.

De PROMs worden aan de patiënt aangeboden als de diagnose wordt gesteld en na respectievelijk 6, 12 maanden behandeling, en vervolgens jaarlijks. Zo kan het verloop van herstel worden gemonitord en kan, op grond van eigen uitkomsten, betrouwbaarder informatie aan de patiënt worden verstrekt voorafgaand aan de behandelkeuze.

Het streven is om alle ziekenhuizen binnen het netwerk deel te laten nemen aan het VBHC-careprogramma en daarmee ook aan de PROMs. Dit vergt investering in infrastructuur en automatisering, maar gezamenlijk hierin optrekken kan schelen in de implementatie- en onderhoudskosten.

Binnen het VBHC-project worden ook de procesindicatoren (bijv. poliklinische doorlooptijden) en de kosten (bijv. aantal polikliniekbezoeken, ingezette middelen) geëvalueerd om te komen tot een efficiëntere en goedkopere bedrijfsvoering. Mogelijk ligt hier voor potentiële partners een incentive om te participeren.

\section{Operatie op locatie en individuele uitkomstenvergelijking}

Om uitkomsten te kunnen verbeteren, is het noodzakelijk om je eigen behandelresultaten te kennen en direct te kunnen vergelijken met die van je collega's. Sinds 2013 worden de operatiecomplicaties, functionele en oncologische uitkomsten (negatieve snijvlakken, klieropbrengsten, postoperatief onmeetbaar PSA) binnen ons centrum iedere drie maanden geëvalueerd [10]. Om zo veel mogelijk objectiviteit te betrachten in de datacollectie worden de individuele prestaties door een verpleegkundig specialist (JdB) prospectief bijgehouden, alsmede de casemixvariabelen, zoals patiënten (waaronder leeftijd en score op de Charlson Comorbidity Index) en tumorkarakteristieken. Verder worden alle operaties digitaal opgenomen en tijdens een kwartaalbespreking wordt casuïstiek niet alleen besproken, maar ook bekeken.

Individuele feedback geeft maximale transparantie, maar is ook confronterend en vraagt derhalve veel onderling vertrouwen. Deze interne kwaliteitsanalyse wordt door alle vier de operateurs als zeer waardevol ervaren. Door op één locatie te opereren, zijn alle externe factoren (zoals assistentie op OK, PA-beoordeling en nazorg op verpleegafdeling) voor alle operateurs gelijk en zijn verschillen in uitkomsten dus enkel terug te voeren op casemix en het handelen van de individuele operateur. Dit faciliteert een eerlijke vergelijking tussen de operateurs. Daarnaast leidt het werken met een vast OK-team tot feedback van de OKverpleegkundigen die ertoe doet.

Het is overigens allerminst het streven om te komen tot een uniforme operatietechniek; het streven is juist om te ontdekken waar de verschillen liggen, en dat dan op detailniveau. Zo is duidelijk geworden dat een van de operateurs meer vrije apicale snijvlakken weet te bereiken en een ander weer een grotere klieropbrengst heeft. Door de driemaandelijkse analyse te laten plaatsvinden in aansluiting op een operatiedag is de mogelijkheid gecreëerd om met elkaar on-sitetechnieken en ook videobeelden te bekijken en te bediscussiëren. Dit directe 'kijken in elkaars keuken' is leerzaam, leuk en verbindend. Logischerwijs zijn de urologen op dat moment dan onttrokken aan de reguliere patiëntenzorg en dit vraagt commitment van collega's en van de organisatie.

Omdat er geopereerd wordt op één locatie zijn de operateurs rechtstreeks met elkaar in contact, met de bijbehorende dynamiek; we kunnen elkaar direct om advies vragen of terugkoppeling geven, en zo nodig stante pede een kijkje nemen op de operatiekamer.

De prostaatbiopten en MRI-beelden van verwezen patiënten worden gereviseerd door collega-pathologen en -radiologen. Met deze double readings hopen we een extra kwaliteitsslag te maken in de onderlinge consensus. $\mathrm{Na}$ een interimanalyse lijkt er overigens een grote interobserver-agreement tussen pathologen, waarbij de vraag rijst of pathologische revisie zinvol is. Dit wordt nog nader bestudeerd.

Om de indicatie voor een radicale prostatectomie en operatieplanning aan te scherpen, is een gemeenschappelijk multidisciplinair overleg (MDO) opgezet middels videoconferenties. Tijdens dit wekelijks MDO worden alle patiënten besproken die voor de week daarna ingepland staan voor een RARP en wordt, aan de hand van tumorkarakteristiek en getoonde MRI-beelden, consensus verkregen over de operatie-indicatie en -planning (al dan niet zenuwsparend, indicatie voor klierdissectie etc.). Omdat dit MDO sinds de toetreding van het Radboudumc is ingesteld, is het effect van deze bespreking op de chirurgische resultaten nog niet geëvalueerd. Binnen dit MDO vindt ook terugkoppeling plaats als er bijvoorbeeld een mismatch blijkt te zijn tussen de definitieve PA-uitkomst en de preoperatief ingeschatte oncologische situatie.

Het opereren op locatie heeft ook nadelen. Het vergt mobiliteit van dokters en patiënten met hun familie. Wanneer het verblijf in het ziekenhuis ongecompliceerd verloopt, wordt - zo leert de ervaring - reistijd niet als een probleem ervaren. Bij complicaties ligt dit anders. Het kan lastig zijn dat de operateur een gecompliceerde postopera- 
tieve fase niet kan begeleiden. Ook dit vraagt om stevig onderling vertrouwen en een goede onderlinge communicatie, mede met patiënt en familie.

\section{Uitvoering van werken op één locatie}

Er heeft relatief veel tijd gezeten tussen de eerste aanzet om op één locatie te gaan werken en de realisatie daarvan. Allereerst moest natuurlijk het gevoel groeien dat alle betrokken collega's op dezelfde lijn zaten ten aanzien van de indicatiestelling voor de prostatectomie. Ook moesten zij beschikken over een zelfkritische attitude en ontvankelijk zijn voor suggesties en commentaar. Daartoe zijn veel oriënterende overlegsessies georganiseerd, waarbij ambitieniveau, visie en doelstellingen op termijn op elkaar werden afgestemd. Zo zijn ook talloze MDO-casuïstiekgesprekken gevoerd, om te kunnen beoordelen of alle betrokkenen vergelijkbare gedachten hadden over best practice. Tevens zijn de zorgpaden van de participerende ziekenhuizen tegen het licht gehouden, om ook in dit opzicht te komen tot een gemeenschappelijk contour die geschikt was om verder uit te werken.

Toen de urologen, verpleegkundig specialisten en raden van bestuur qua gedachtegoed op één lijn zaten, moesten financiële en juridisch zaken worden beslecht. Met drie verschillende ziekenhuizen, met daarbij ook drie verschillende vormen van maatschapfinanciering medisch specialistisch bedrijf, loondienst en vakgroepfinanciering werden de financiële en juridische uitdagingen en implicaties duidelijk. Afspraken c.q. contracten hieromtrent hebben veel tijd gekost.

Al met al heeft het een klein jaar geduurd voordat het Radboudumc het derde participerende ziekenhuis werd in de reeds bestaande samenwerking tussen CZE en CWZ.

\section{Transmuraal zorgpad}

Het vermoeden van prostaatkanker en de zorg hieromtrent begint en eindigt bij de huisarts. Daartussenin liggen verschillende momenten van medisch-specialistische zorg. De diagnostiek en behandeling zijn multidisciplinair en verlopen via zorglijnen. Dit maakt het uitermate belangrijk dat de informatievoorziening en zorg tussen huisarts en specialist goed op elkaar aansluiten en dat patiënten bij verwijzing goed geïnformeerd zijn over het te verwachten traject.

Vanaf het moment dat de patiënt een verzoek doet tot een PSA-test krijgt hij van de huisarts en de uroloog dezelfde informatie. Hiervoor is, in samenwerking met de Organisatie van Chronische Eerstelijnszorg (OCE) Nijmegen, Maasziekenhuis Pantein (locatie Boxmeer), CWZ en Radboudumc een keuzehulp ontwikkeld voor het al dan niet laten bepa- len van het serum-PSA. Er zijn afspraken gemaakt over de timing van de stappen in de vervolgdiagnostiek en -behandeling, en worden patiënten - na negatieve diagnostiek terugverwezen naar de huisarts. Zo krijgt de huisarts een grotere rol in het diagnostisch traject en de nazorg, en zijn er minder medisch-specialistische controles nodig. Dit ontlast de urologische praktijk en reduceert kosten.

In geval van de diagnose prostaatkanker wordt een behandeladvies geformuleerd en wordt de patiënt ondersteund door een keuzehulp om tot een behandelkeuze te komen. Vaak gaat het om moeilijke afwegingen, waarin levensduur, levenskwaliteit en behandelrisico's tegen elkaar afgewogen moeten worden. Hierbij is persoonlijke begeleiding nodig. De huisarts kent de keuzehulp die gehanteerd wordt en helpt de patiënt om alles nog eens op een rijtje te zetten, en draagt zo bij aan een zorgvuldige afweging.

Volgens het NHG-Standpunt 'Oncologische zorg in de huisartsenpraktijk' is een belangrijke rol van de huisarts bij patiënten met kanker 'het waarborgen van continue en persoonsgerichte zorg', waarbij de huisarts ook 'het proces van gedeelde besluitvorming en zelfmanagement' ondersteunt [11]. Verder wordt de huisarts binnen 24 uur geïnformeerd over de uitkomst van het multidisciplinair overleg (MDO) en na ontslag uit het ziekenhuis. Dankzij deze samenwerkingsafspraken is de huisarts snel en volledig op de hoogte van het behandelplan en de situatie van zijn patiënten en daarmee ook in staat om deze begeleiding naar behoren uit te voeren. Wanneer de patiënt behandeld is in het ziekenhuis, verricht de huisarts een belangrijk deel van de verdere medische en psychosociale begeleiding. De huisarts voert ook een deel van de oncologische controles na radicale prostatectomie uit, mits de oncologische situatie dit toelaat. Vanaf twee jaar na behandeling voert de huisarts zelfs alle controles uit.

Deze procedure leidt ertoe dat de patiënt sneller over de lijnen van zorg gaat, wat vraagt om een stevigere regie c.q. begeleiding binnen het zorgnetwerk. Hier ligt de rol voor de casemanager, die te allen tijden weet in welke fase van de routing de patiënt zich bevindt, en daardoor ook als aanspreekpunt voor de patiënt kan fungeren.

Om de kennis van de huisartsen actueel te houden, geven de urologen die deelnemen aan dit project regelmatig nascholing aan huisartsen. Deze pilot transmurale prostaatkankerzorg is mogelijk gemaakt dankzij financiële steun van CZ. De ambitie is om een dergelijk transmuraal zorgtraject na een succesvolle pilot in een grotere regio te implementeren, en te starten met het uniformeren van informatie en zorgpaden. 
Hier staat een advertentie.

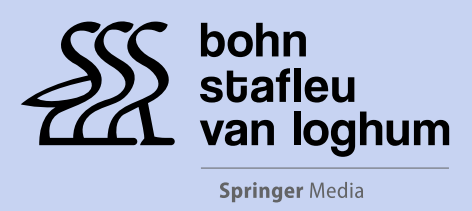

Houten 2017 
Hier staat een advertentie.

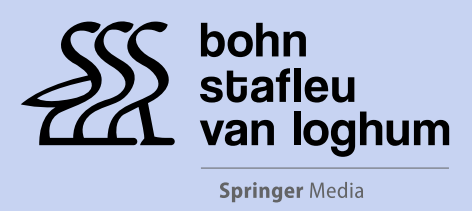

Houten 2017 
Hier staat een advertentie.

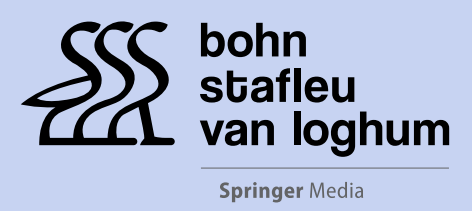

Houten 2017 
Hier staat een advertentie.

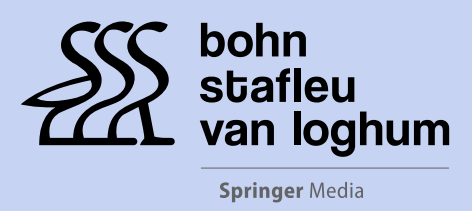

Houten 2017 


\section{De CPCN-gedachte}

Het CPCN moet ervoor zorgen dat patiënten overal, onafhankelijk van de plek waar zij hun zorgtraject starten, kunnen rekenen op optimale prostaatkankerzorg, op zo kort mogelijke termijn, volgens de laatste stand van de wetenschap, diagnostiek, behandeling en ervaringsdeskundigheid. Dit vraagt om onderlinge regionale afstemming en afspraken [12].

De complexiteit van de moderne diagnostiek (bijv. ${ }^{68}$ Gallium PSMA-PET CT en nano-MRI) en behandeling (bijv. RARP, Radium-223, PSMA-Actinium) vraagt om een andere organisatie van de prostaatkankerzorg, waarbij de uitdaging is deze zorg continu te optimaliseren met beheersing van de kosten.

Een CPCN zien we als een samenwerkingsverband tussen zorgaanbieders in de eerste, tweede en derde lijn, gericht op persoonlijke hoogwaardige prostaatkankerzorg in een brede regio. Deze regio zal meestentijds bepaald worden door reeds bestaande samenwerkingsverbanden en verwijspatronen en hoeft dus niet voor alle tumorsoorten identiek te zijn. Binnen het CPCN worden concrete afspraken gemaakt over de inhoudelijke organisatie van de zorg, monitoring en kwaliteitsverbetering (zoals hiervoor beschreven). Het gaat om duidelijke normen die getoetst worden, om transparantie en om vertrouwen. Er worden juridische kaders geformeerd om de onderlinge afspraken te borgen. Het CPCN is tevens het platform voor wetenschappelijk onderzoek, verspreiding van kennis, onderwijs en innovatie.

Dat complexe behandelingen vragen om concentratie, behoeft geen betoog. Dat geldt voor radicale prostatectomie, brachytherapie, complexe diagnostiek, maar ook voor nieuwe ontwikkelingen in radiotherapie en medische oncologie (zoals personalised immunotherapy). Oncologische zorg is niet gebaat bij versnippering over diverse locaties. Wij vinden overigens beslist niet dat alles onder één dak moet, maar stellen ons een CPCN voor waarbij expertisegevoelige diagnostiek en behandeling geconcentreerd is. Voor onze regio betekent dit concreet dat de 68 Ga-PSMAPET en nano-MRI plaatsvinden in het Radboudumc, de RARP'en in het CWZ en brachytherapie in het CZE. Informatievoorziening, patiëntbegeleiding en reguliere diagnostiek en behandeling, zoals multiparametrische MRI en prostaatbiopten (MR-TRUS-fusie) en systemische palliatieve behandeling, vinden idealiter plaats op elke CPCNlocatie. Daarbij hebben patiënten behoefte aan (na)zorg die zich zo dicht mogelijk bij huis bevindt, waarbij er behoefte is aan afstemming van zorg tussen lokale uroloog en huisarts.

Omdat zorg meer zal worden afgestemd op persoonlijke behoeften en mogelijkheden, zal de patiënt zijn eigen traject afleggen door de lijnen van de zorg en binnen het netwerk. Maar mogelijk zullen patiënten er soms voor kiezen om een deel van de behandeling zelfs te laten plaatsvinden buiten het CPCN. Vanuit het netwerk wordt middels MDO een zorgplan (zorgtraject) geboden, maar zal ook de regie moeten zijn geborgd; voor patiënten moet op elk moment duidelijk zijn bij wie zij terecht kunnen in geval van nood.

Het is nadrukkelijk (en vanzelfsprekend) de bedoeling om met de collega's samen een CPCN op te bouwen met respect voor een ieders expertise. Binnen het CPCN zullen, in gezamenlijkheid, uniforme (transmurale) zorgpaden worden uitgewerkt die zijn gericht op integrale ketenzorg, waarbij het perspectief van de patiënt, en de kwaliteit en doelmatigheid van de zorg, leidend zijn. Er zijn afspraken vastgelegd over triage, verwijzing, samenwerking (waaronder MDO en derdelijnsconsultatie), behandeling, nazorg en follow-up.

\section{Wetenschappelijk platform}

Door bundeling van krachten en volumevergroting vormt het CPCN bij uitstek een platform voor klinische trials en voor implementatie en evaluatie van nieuwe behandelingen. Als grotere aantallen patiënten meedoen in klinische studies kunnen deze studies sneller tot nieuwe inzichten leiden.

Dat bundeling van informatie soms tot verassende uitkomsten leidt, is gebleken uit het Santeon-project $\mathrm{ZvU}$. Zo kwam uit de retrospectieve analyses naar voren dat de langetermijnoverleving van de active-surveillance patiënten minder gunstig lijkt dan de overleving van direct behandelde patiënten. Dit verschil bleef zichtbaar, ook na correctie voor patiëntkenmerken. Een mogelijke verklaring voor het verschil in overleving is dat sommige patiënten met een laagrisicoprofiel, op basis van de klinische gegevens, een te lage tumorstadiëring krijgen (understaging). Op grond van deze uitkomst lijkt een verbeterde diagnosestelling noodzakelijk om het risico op deze understaging te minimaliseren. Betere diagnosestelling zou bijvoorbeeld kunnen door het inzetten van MRI-echo-fusiebiopten, juist voor patiënten die in aanmerking komen voor active surveillance.

In Santeon-verband is eind 2014, in samenwerking met het UMC Utrecht en het Radboudumc, de FUTURE-trial gestart, om te onderzoeken wat de beste methode is om met behulp van MRI-beelden - gericht biopten van afwijkingen in de prostaat te nemen. Dit onderzoek vindt plaats in het St. Antonius Utrecht/Nieuwegein en het CWZ. Door een platform van participerende ziekenhuizen kon snelle inclusie worden bereikt.

De huidige regionale samenwerking op locatie heeft als voordeel dat datacollectie door lokale data-analysten op één locatie plaatsvindt. Dit geeft meer commitment en controle en is efficiënter dan uitvoering op meerdere locaties. Zo wordt binnen het wekelijks MDO besproken of patiënten 
geïncludeerd kunnen worden in de Magnify-study, waarbij pre- en postoperatief een ${ }^{68}$ Gallium PSMA-PET-CT en nano-MRI wordt verricht bij intermediate en high risk prostaatcarcinoom. Het primaire doel van dit onderzoek is histologische validering van ${ }^{68}$ Gallium PSMA-PET-CT en nanoMRI, maar ook wordt onderzocht of betere beeldvorming voorafgaand aan pelviene klierdissectie leidt tot een beter oncologisch resultaat.

Zoals hiervoor beschreven, is de Santeon-indicatorenset ontwikkeld in samenwerking met ICHOM. Daarmee is de mogelijkheid ontstaan om te vergelijken met gerenommeerde buitenlandse klinieken. Binnen Santeon worden data in gevoerd in het data-collection center van de $\mathrm{Mo}$ vember-foundation om tot internationale benchmarking te komen (Movember-project).

\section{Conclusie}

In dit artikel hebben we geschetst hoe wij menen dat, binnen een brede regio, verdere samenwerking zou kunnen worden ontwikkeld vanuit de gemeenschappelijke professionele ambitie om de prostaatkankerzorg zo kostenefficiënt mogelijk te maken, door vanuit verschillende disciplines zo veel mogelijk expertise te concentreren, en middels een intensief samenwerkingsverband tussen de zorgaanbieders in de eerste tweede en derde lijn te streven naar uniformering van informatie en zorgtrajecten en afname van uitkomstvariatie middels monitoring van indicatoren.

Binnen het netwerk worden mogelijkheden geboden om persoonlijke zorg te leveren die is afgestemd op de individuele behoefte en wensen van de patiënt. Door gezamenlijk op te trekken binnen het regionale CPCN ontstaat een uniek platform voor value based health care, kennis en wetenschap, onderwijs en innovatie. Wij nodigen u van harte uit uw expertise in te brengen!

Open Access This article is distributed under the terms of the Creative Commons Attribution 4.0 International License (http:// creativecommons.org/licenses/by/4.0/), which permits unrestricted use, distribution, and reproduction in any medium, provided you give appropriate credit to the original author(s) and the source, provide a link to the Creative Commons license, and indicate if changes were made.

\section{Literatuur}

1. Skipr.nl. CZ wil prostaatkankerzorg concentreren in drie centra. 2016. https://www.skipr.nl/actueel/id26354-cz-wil-prostaat kankerzorg-concentreren-in-drie-centra.html. Geraadpleegd op: 29 apr 2016.

2. NOS. 'Beperk alle prostaatkankeroperaties tot twee ziekenhuizen'. 2016. http://nos.nl/artikel/2117609-beperk-alle-prostaat kankeroperaties-tot-twee-ziekenhuizen.html. Geraadpleegd op: 15 mei 2017.

3. Poel H van der, Stienen J, Wijsman B. NVU Kwaliteitsregistraties Prostatectomie. Tijdschr Urol. 2017;4:2-6.

4. Morsch J, Mathes T, Pieper S. Relationship between surgeon volume and outcomes: a systematic review of systematic reviews. Syst Rev. 2016;4:204.

5. Gershman B, Meier SK, Jeffery MM, et al. Redefining and contextualizing the hospital volume-outcome relationship for robot-assisted radical prostatectomy: implications for centralization of care. J Urol. 2017;198:92-9.

6. Basten JPA van, Bosch WF van den, Niessen LM, Vrijhof E. Moving prostatectomies to a high volume center. NEJM Catalyst. 2015. http://catalyst.nejm.org/moving-prostatectomies-to-a-highvolume-center-2/. Geraadpleegd op: 24 okt 2015.

7. Uitkomstenboek. Zorg voor Uitkomst Uitkomstindicatoren voor kanker. 2014. http://www.zorgvoorverbetering.nl/uitkomstenboek 2014.pdf. Geraadpleegd op: 1 dec 2016.

8. Borne B van den, Korthorst R, Schramel F, Somford R. De motor achter kwaliteitsverbetering bij de Santeon-ziekenhuizen. 2015. https://www.medischcontact.nl/nieuws/laatste-nieuws/ artikel/Uitkomst-meten-begint-te-renderen.htm. Geraadpleegd op: 17 apr 2017.

9. Morgans AK, Bommel ACM van, Stowell S, Abrahm JL, et al. Development of a standardized set of patient-centered outcomes for advanced prostate cancer: an international effort for a unified approach. Eur Urol. 2015;68:891-8.

10. Basten JP van, Schramel F. Indicatoren: Wat telt is de uitkomst. 2014. https://www.medischcontact.nl/nieuws/laatstenieuws/artikel/indicatoren-wat-telt-is-de-uitkomst.htm. Geraadpleegd op: 2 mei 2017.

11. NHG. NHG-Standpunt 'Oncologische zorg in de huisartsenpraktijk’. 2016. https://www.nhg.org/sites/default/files/content/nhg org/uploads/nhg-standpunt_oncologische_zorg.pdf. Geraadpleegd op: 15 mei 2017

12. Koersboek. Koersboek oncologische Netwerkvorming. 2015. http://koersboek-oncologische-netwerkvorming.nl. Geraadpleegd op: 18 mrt 2017.

dr. Jean-Paul A. van Basten uroloog

dr. Rik M. Somford uroloog

Joost de Baaij verpleegkundig specialist

dr. Michiel Sedelaar uroloog

dr. Eric Vrijhof uroloog 